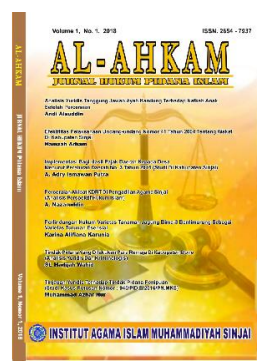

\title{
ANALISIS PENGADAAN TANAH UNTUK KEPENTINGAN UMUM BAGI PELAKSANAAN PEMBANGUNAN PELEBARAN JALAN RAYA DI SULAWESI SELATAN (STUDI PEMBANGUNAN PELEBARAN JALAN RAYA TRANS NASIONAL MAROS-BARRU)
}

\author{
Hamzah Arhan', Andi Mukramuddin AR ${ }^{2}$, Andi Alauddin ${ }^{3}$ \\ ${ }^{l}$ IAI Muhammadiyah Sinjai, Jln.Sultan Hasanuddin, Kab.Sinjai \\ ${ }^{2}$ Mahkamah Agung Republik Indonesia, Jakarta, Indonesia. \\ ${ }^{3}$ IAI Muhammadiyah Sinjai, Jln.Sultan Hasanuddin, Kab.Sinjai
}

\begin{abstract}
Abstrak
Penelitian ini bertujuan untuk mengetahui proses pengadaan tanah untuk kepentingan umum terhadap pelaksanaan pembangunan pelebaran jalan raya di Sul-Sel dan faktor yang mempengaruhinya. Metode yang digunakan adalah pendekatan yuridis (statute approach) dan pendekatan empiris dimana menggunakan data primer dan sekunder. Hasil penelitian: Proses pelaksanaan pengadaan tanah bagi pembangunan untuk kepentingan umum Yang dilaksanakan di Sul-Sel tepatnya pada pelebaran jalan nasional poros MarosBarru dididasarkan pada PerPres Nomor 65 Tahun 2006 serta peraturan pelaksananya dalam Peraturan Kepala BPN RI Nomor 3 Tahun 2007, namun secara menyeluruh pengadaan tanah di Sul-Sel pada pembangunan jalan raya Nasional poros Maros-Barru belum optimal. Faktor yang mempengaruhi pengadaan tanah untuk kepentingan umum di Sul-Sel pada pembangunan jalan nasional Maros-Barru adalah substansi hukum, struktur hukum, peran serta masyarakat dan ganti rugi. Untuk pemerintah agar memahami secara menyeluruh mengenai aturan pengadaaan tanah bagi pembangunan untuk kepentingan umum. Perlu adanya aturan pengadaan tanah untuk kepentingan umum yang dapat mengakomodasi kepentingan pemerintah dan masyarakat, seyogyanya aparatur pelaksana yang terlibat dalam pengadaan tanah lebih memantapkan penguasaan mengenai aturan pengadaan tanah dan susunan kepanitiaan melibatkan unsur yudikatif, dalam hal peran serta masyarakat perlu mengintensifkan penyuluhan hukum mengenai pertanahan, masalah ganti rugi harus tetap mengedepankan prinsip keadilan, keseimbangan dan menjungjung tinggi hak-hak asasi manusia.
\end{abstract}

Kata Kunci : Pengadaan tanah, Pelebaran, Jalan

\section{Pendahuluan}

Tanah merupakan suatu hal yang tidak dapat dipisahkan dalam kehidupan umat manusia karena merupakan kebutuhan dasar manusia. Sejak lahir sampai meninggal dunia, manusia membutuhkan tanah untuk tempat hidupnya. Olehnya itu tanah merupakan suatu kebutuhan yang sangat penting, sehingga demikian pentingnya sehingga Jean Jequges Rousseau menempatkan tanah rakyat sebagai bagian dari teori kontrak sosial (sosial contract). 


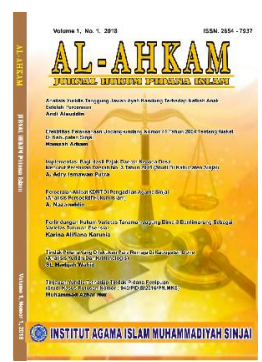

Di Era globalisasi sekarang ini yang dimana manusia sangat ingin didalam kehidupannya serba efektif dan efesien olehnya itu menuntut pembangunan didunia dan khususnya di Indonesia sangat cepat. Disatu sisi pembangunan yang cepat itu menuntut adanya penyedian lahan yang cepat namun disisi lain kenyataannya penyedian tanah tersebut mengalami banyak masalah diantaranya lahan yang tersedia semakin terbatas seiring dengan pertumbuhan penduduk yang sangat pesat dan juga pembangunan tersebut harus sesuai dengan konsep pembangunan nasional yaitu pembangunan yang berkelanjutan dimana pemanfaatan dan pengelolaan sumber daya alam bagi kebutuhan generasi sekarang juga mempertimbangkan dan memperhatikan generasi mendatang dalam memenuhi kebutuhannya.

Melalui hak menguasai dari Negara inilah maka Negara selaku badan penguasa akan dapat senantiasa mengendalikan atau mengarahkan pengelolaan fungsi bumi, air dan ruang angkasa serta kekayaan alam yang terkandung didalamnya sesuai dengan peraturan dan kebijakan yang ada, yaitu dalam lingkup penguasaan secara yuridis yang beraspek publik (Muhammad Bakri 2007 : 5)

Olehnya itu Negara dalam hal ini pemerintah dituntut membuat kebijakan atau aturan-aturan untuk mengendalikan dan mengarahkan pengelolaan fungsi bumi, air dan ruang angkasa, dan khusus untuk pengadaan tanah pemerintah telah membuat aturan-aturan yang di tuangkan dalam Undang-undang Nomor 2 Tahun 2012 Tentang Pengadaan Tanah Bagi Pembangunan Untuk Kepentingan Umum yang diundangkan pada 14 Januari 2012, Peraturan Peresiden Nomor 36 Tahun 2005 Jo. Peraturan Peresiden Nomor 65 Tahun 2006 Tentang Pengadaan Tanah Bagi Pelaksanaan Pembangunan Untuk Kepentingan Umum, Peraturan Kepala Badan Pertanahan Nasional RI Nomor 3 Tahun 2007 Tentang Ketentuan Pelaksanaan Peraturan Peresiden Nomor 36 Tahun 2005 Jo. Peraturan Peresiden Nomor 65 Tahun 2006 Tentang Pengadaan Tanah Bagi Pelaksanaan Pembangunan Untuk Kepentingan Umum, lalu Peraturan Menteri Keuangan Nomor 58/PMK.02/2008 Biaya Panitia Pengadaan Tanah Bagi Pelaksanaan

Mengenai kebijakan otonomi daerah, wewenang penyelenggaraan penataan ruang dilakukan oleh pemerintah dan pemerintah daerah, yang mencakup kegiatan pengaturan, pembinaan, pelaksanaan, dan pengawasan penataan ruang, didasarkan pada pendekatan wilayah dengan batasan wilayah administratif. Dengan pendekatan wilayah administratif tersebut, penataan ruang seluruh ielaya Negara kesatuan Republik Indonesia terdiri atas wilayah nasional, wilayah provinsi, wilayah kabupaten, dan wilayah kota, yang setiap wilayah tersebut merupakan subsistem ruang menurut batasan administratif, didalam subsistem tersebut, terdapat sumber daya manusia dengan berbagai macam pemanfaatan sumber daya alam dan sumber daya buatan, dan dengan tingkat pemanfaatan ruang yang berbeda-beda, yang apabila tidak ditata dengan baik, 


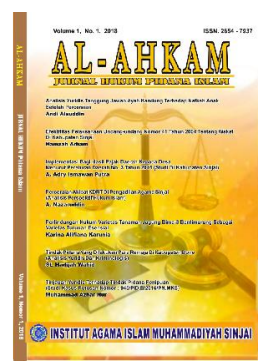

dapat mendorong kearah ketidak seimbangan pembangunan antarwilayah serta ketidaksinambungan pemanfaatan ruang. (Arie Sukanti Hutagalung dan Markus Gunawan 2009 : 114)

Pada masa sekarang ini sangat sulit melakukan Pembangunan Untuk Kepentingan Umum di atas tanah Negara, dan sebagai jalan keluar yang ditempuh adalah Negara dalam hal ini Pemerintah harus menyediakan tanah dengan cara memberi ganti kerugian yang layak dan adil kepada pihak yang berhak, dengan jalan musyawarah dan apabila tidak terjadi kesepakatan pihak yang berhak dapat mengajukan upaya hukum ke Pengadilan ( Pasal 38 Undang-undang Nomor 2 Tahun 2012).

Kemudian menurut Undang-undang Nomor 20 Tahun 1961, bahwa apabila tidak terjadi sepakat dalam musyawarah atau tidak mendapatkan jalan keluar maka dapat di tempuh dengan cara pencabutan hak atas tanah, walaupun kepemilikan tanah merupakan sebuah hak asasi manusia dalam artian bahwa pemilik hak atas tanah mempunyai hak untuk mengunakan atau tidak menggunakan tanah miliknya tersebut (sifatnya abadi), tetapi didalam hak milik atas tanah bisa dicabut karena tanah memiliki fungsi sosial (menurut Undangundang Nomor 5 tahun 1960), dan hal ini kadang menimbulkan konfilk dan masalah-masalah yang berkepanjangan.

Seperti halnya pengadaan tanah di trans Maros-Barru yang juga mengalami banyak masalah antara lain sulitnya kata sepakat antara pemilik hak dengan pemerintah dalam hal ganti kerugian, hal inilah yang menjadi salah satu kendala sehingga proyek pelebaran jalan Maros-Barru sepanjang 120 kilometer yang dimulai sejak tahun 2008 kemudian proyek tersebut ditargetkan rampung pada 2010 dan terus mulur sampai sekarang. Kemudian selama periode 20082012, pembenahan jalan utama Maros-Barru telah menghabiskan biaya APBN lebih dari Rp 1 triliun.

Di Kabupaten Barru, proyek pelebaran Trans Sulawesi yang panjangnya sekira $87 \mathrm{~km}$ masih terdapat beberapa titik yang belum rampung. Selain masalah pembebasan lahan juga beberapa titik sambungan mulut jembatan belum selesai dilaksanakan pekerjaannya. Juga beberapa lokasi terkendala pembongkaran rumah warga. Di Kecamatan Mallusetasi, misalnya, masih ada dua titik yang sama sekali tak bisa dikerja karena terkendala harga pembebasan. Seperti di Bojo Baru dan Labuange.

Hal yang sama terjadi di Trans Sulawesi di wilayah Pangkep, beberapa ruas jalan yang dipadati kendaraan yang ingin melintas, di antaranya terdapat di Jembatan Kalibone-perbatasan Pangkep dan Maros, di Jalan Kemakmurankompleks Ruko Palampang, Jalan Ambarala- perempatan poros Makassar Parepare-Tonasa II, serta jalan poros yang melintas di Kecamatan Segeri. Di ruas- 


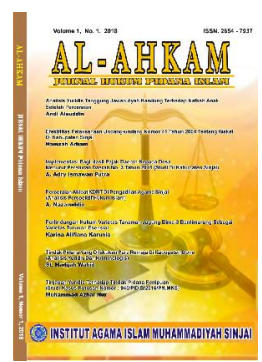

ruas jalan tersebut, pelebaran jalan belum tuntas dilakukan sebab masih terkendala pembebasan lahan.

Terhitung sedikitnya ada lima ruas jalan yang masih terpotong. Kesemuanya terdapat di wilayah Kecamatan Ma'rang, Segeri hingga Kecamatan Mandalle.

Hingga saat ini, lahan yang belum bebas hanya berkisar 2,0 km (sebagian sisi kiri dan kanan) yang tersebar di sembilan titik dengan jumlah pemilik sebanyak 106 kepala keluarga (KK).

Olehnya itu menurut penulis memandang sangat menarik dan penting untuk mengangkat masalah ini dalam penelitian tesis dengan judul "Analisis Pengadaan Tanah Untuk Kepentingan Umum Bagi Pelaksanaan Pembangunan Pelebaran Jalan Raya Di Sulawesi Selatan (Studi Pembangunan Pelebaran Jalan Raya Trans Nasional Maros-Barru).

\section{Tinjauan Pustaka}

Landasan hukum dalam hal pengadaan tanah untuk pembangunan antara lain adalah Undang-Undang Dasar Negara Republik Indonesia Tahun 1945 Pasal 33 ayat (3), Undang-Undang Nomor 5 Tahun 1960 mengenai Peraturan Dasar Pokok Agraria, Undang-Undang Nomor 2 Tahun 2012 tentang Pengadaan Tanah Bagi Pembangunan Untuk Kepentingan Umum, Pepres No. 35 tahun 2005. Pepres No. 65 Tahun 2006 tentang Pengadaan Tanah Bagi Pembangunan Untuk Kepentingan Umum, Peraturan Kepala Badan Pertanahan Nasional Nomor 3 Tahun 2007 dan Peraturan Menteri Keuangan Nomor.58/PMK.02/2008.

Tanah merupakan modal dasar pembangunan, dimana hampir tidak ada kegiatan pembangunan (sektoral) yang tidak memerlukan tanah. Oleh karena itu, tanah memegang peranan yang sangat penting, bahkan menentukan berhasil tidaknya suatu pembangunan, olehnya pembangunan disini merupakan variable yang terpengaruh (dependend variable) dan variable yang mempengaruhi adalah pengadaan tanah (Independend Variable), karena dalam hal pembangunan maka yang subtansial adalah pengadaan tanah untuk mewujudkan pembangunan tersebut.

Titik berat pembangunan adalah peningkatan masyarakat untuk mandiri di dalam mencapai kesejahteraan (self empowerment) secara berkelanjutan, untuk mencapai hal tersebut maka lahan atau pengadaan tanah harus disiapkan untuk mendukung hal tersebut, kemudian dalam hal pengadaan tanah tersebut harus dengan proses yang sesuai dengan aturan yang ada dan dalam hal pengadaan tanah issue yang sering mencuat adalah mengenai persoalan ganti rugi. Ganti rugi yang diberikan oleh pemerintah juga harus mampu memenuhi rasa keadilan dengan tetap memperhatikan penghormatan terhadap hak-hak yang sah atas tanah

Dalam hal pengadaan tanah tersebut peran pemerintah dan peran serta masyarakat sangat penting karena keduanya adalah kunci untuk dapat 
merealisasikan pembangunan tentunya dengan lahan yang telah ada. Pemerintah dan masyarakat harus saling bekerja sama yaitu walaupun dilaksanakan oleh pemerintah yang mewakili negara atas tanah sebagai amat dari Pasal 33 ayat (3) Undang-Undang Dasar 1945 pada prinsipnya kebijakan pemerintah harus tetap memperhatikan dan melaksanakan penghormatan hak atas tanah, disisi lain peran serta masyarakat juga sangat penting dalam hal untuk mewujudkan kebijakankebijakan pemerintah tersebut yang tujuannya adalah untuk kesejahteraan masyarakat.

Kebijakan-kebijakan pemerintah berupa aturan-aturan juga harus mengakomodasi kepentingan pemerintah dan masyarakat, karena aturan-aturan tersebut akan berdampak sangat besar dalam kehidupan bangsa dan negara untuk mewujudkan kepastian, keadilan dan kemanfaatan hukum. Faktor-faktor yang mempengaruhi terwujudnya pembangunan tersebut diatas adalah merupakan masalah klasik, dimana seharusnya pemerintah dapat menyelesaikannya dengan melaksanakan pembangunan sesuai dengan peraturan-peraturan yang ada disamping itu pemerintah juga harus melihat kesejahteraan terhadap masyarakat yang terkena dampak pembangunan tersebut dan melakukan ganti rugi yang sesuai dengan rasa keadilan masyarakat agar dalam pengadaan tanah untuk pembangunan dapat optimal yang berimbas pada peningkatan kesejahteraan masyarakat.

Adapaun kerangka konseptual yang dikembangkan pada penelitian ini tercermin pada gambar 1 berikut ini :

\section{Diagram Kerangka Konsep}




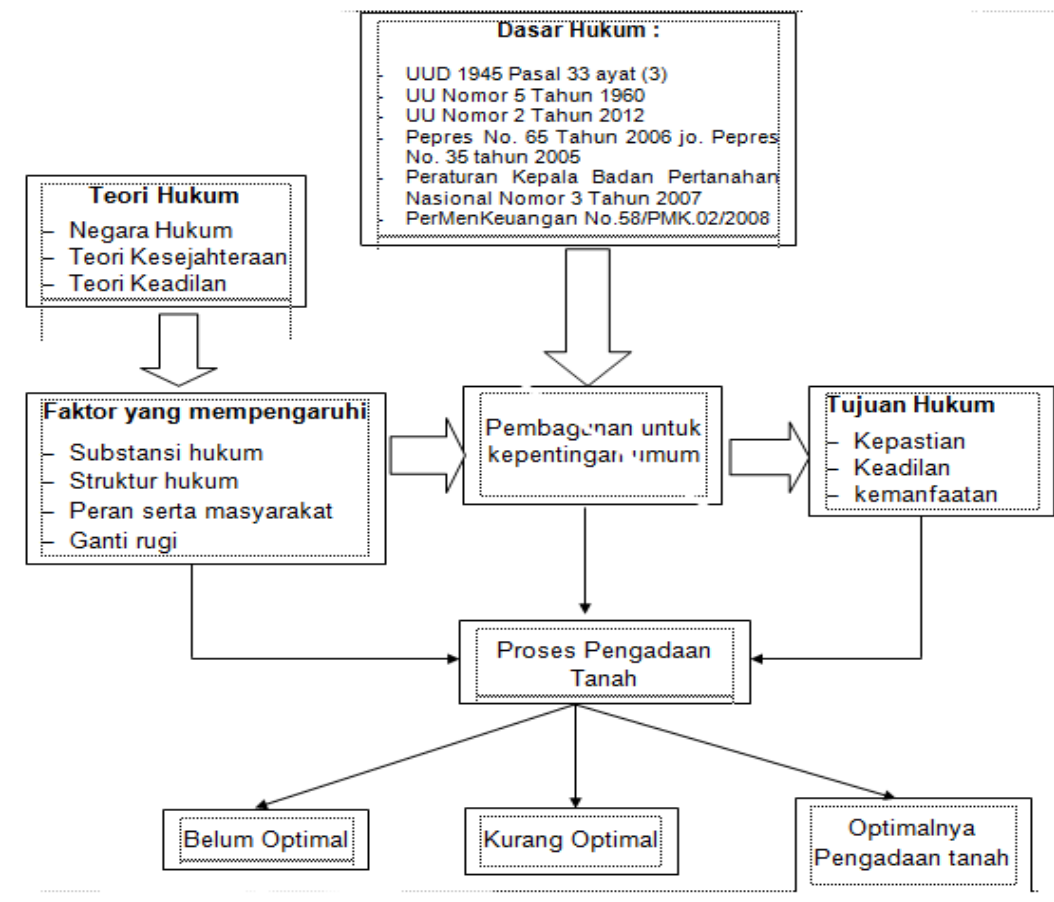

\section{Metode Penelitian}

\section{Tipe dan Pendekatan Penelitian}

Pendekatan yang digunakan dalam penelitian ini adalah pendekatan yuridis atau pendekatan perundang-undangan (statute approach) dan pendekatan empiris. Maksud dari pendekatan yuridis atau pendekatan perundangan-undangan menelaah semua undang-undang dan regulasi yang bersangkut paut dengan isu hukum yang dihadapi, kemudian pendekatan empiris pada penelitian ini adalah penelitian melalui pendekatan lapangan atau bagaimana yang terjadi dilapangan terhadap suatu kasus hukum yang ada di masyarakat.

Pendekatan yuridis perundang-undangan dalam penelitian ini adalah mengamati dan menganalisis bagaimana aturan perundang-undangan mengakomodasi kepentingan negara dan masyarakat kemudian bagaimana peraturan perundang-undangan dapat menyelesaikan permasalahan-permasalahan hukum yang ada di masyarakat, dengan melalui atau mengamati isu hukum secara empiris atau pengamatan fakta dilapangan. Dalam hal ini mengenai kasus pelebaran jalan trans Maros sampai Barru. Jadi bagaimana aturan perundangundangan dapat mengakomodasi kentingan-kepentingan masyarakat dan negara guna untuk kesejahteraan dan keadilaan, lalu menganalisis fakta di lapangan yaitu bagaimana proses pengadaan tanah, lalu ganti kerugian dan lain-lain, apakah telah sesuai dengan aturan hukum yang berlaku. 


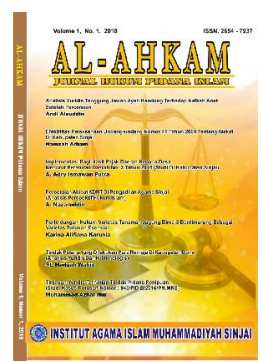

\section{Lokasi Penelitian}

Penelitian ini dilakukan pada di sepanjang jalan maros hingga barru, dimana daerah sepanjang $120 \mathrm{~km}$ yaitu jalan raya poros Maros hingga Barru yang dilebarkan yang masuk kedalam wilayah administratif Kecamatan Maros Baru, Maros Utara, Mandai, ini untuk di Kabupaten maros, di Kabupaten Pangkep terdapat beberapa Kecamatan yaitu : Kecamatan Soreang, Pangkajenne, Bungoro, Labakkang, , Bonto-Bonto, Ma'rang, Sigeri, Mandalle, dan juga meliputi Wilayah Kelurahan Kanaoengan, Tiempae. Lalu di Kabupaten Barru yaitu Kecamatan Tanete Rilau, Soppeng Riaja, dan Mallusetasi, juga terdapat Kelurahan Laboso dan Palanro.

\section{Jenis dan Sumber Data Penelitian}

Data yang dikumpulkan dalam penelitian ini adalah data primer (utama) dan data sekunder (pendukung).

1. Data primer, yaitu data yang diperoleh langsung dari masyarakat.Data primer ini diperoleh melalui kuisioner, yaitu menyediakan suatu daftar pertanyaan berstruktur kepada responden, tetapi tidak menutup kemungkinan adanyavariasi pertanyaan. Kemudian tidak menutup kemungkinan melakukan wawancara dengan pihak yang berwenangdan terkait serta berkompeten khususnya pengadaan tanah bagi pembangunan untuk kepentingan umum dalam pembangunan pelebaran jalan trans nasional yaitu Maros sampai Barru. Melalui wawancara, peneliti akan memperoleh data sesuai dengan keinginan dan permasalahan yang akan dibahas.

2. Data sekunder ini digunakan untuk memecahkan masalah, data sekunder disini yaitu data yang diperoleh dari hasil penelitian pustaka dengan cara mempelajari dan memahami buku-buku atau literatur, serta ketentuanketentuan hukum dan kebijakan-kebijakan pemerintah yang berhubungan dengan pengadaan tanah bagi pelaksanaan pembangunan untuk kepentingan umum, guna menunjang penelitian.

\section{Analisis dan Pembahasan Gambaran Umum Lokasi Penelitian}

Secara geografis wilayah darat Provinsi Sulawesi Selatan dilalui oleh garis khatulistiwa yang terletak antara 00 12' 80 Lintang Selatan dan 1160 48' 122' 36' Bujur Timur, yang berbatasan dengan Provinsi Sulawesi Barat di sebelah utara dan Teluk Bone serta Provinsi Sulawesi Tenggara di sebelah timur, serta berbatasan dengan Selat Makassar di sebelah barat dan Laut Flores di sebelah timur. Luas wilayah Provinsi Sulawesi Selatan khususnya wilayah daratan mempunyai luas kurang lebih 45.519,24 km2, dimana sebagian besar wilayah daratnya berada pada jazirah barat daya Pulau Sulawesi serta sebagian lainnya berada pada jazirah tenggara Pulau Sulawesi. 


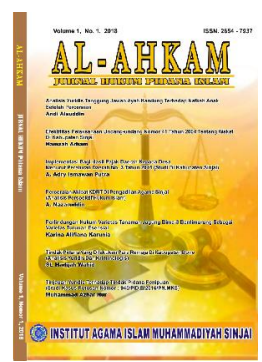

Pola penggunaan tanah daerah ini adalah sebagai berikut : luas pekarangan $1,96 \%$ dari luas propinsi, tegalan dan ladang $13,30 \%$, penggembalaan $5,1 \%$, tambak kolam dan rawa $2,6 \%$, perkebunan $4,26 \%$ dan sawah $7,84 \%$, hutan $30,44 \%$, tanah yang sementara belum diusahakan dan tanah untuk kayu-kayuan dan lainnya 34,41\%. Secara administratif, Sulawesi Selatan terdiri 3 kotamadya dan 21 kabupaten, 304 kecamatan dan 2.953 desa/kelurahan.

Setelah adanya pemekaran provinsi Sulawesi Selatan menjadi 2 (dua) provinsi Sulawesi Selatan (Sulsel) dan Sulawesi Barat (Sulbar), panjang jalan nasional dan provinsi di provinsi Sulsel berkurang menjadi $2.765,53 \mathrm{~km}$. Masingmasing jalan nasional sepanjang $1.556,13 \mathrm{~km}$ dan jalan provinsi sepanjang $1.209,40 \mathrm{~km}$, secara umum kondisi jalan nasional di wilayah kerjanya, kondisi baik $927,76 \mathrm{~km}$, sedang $586,82 \mathrm{~km}$, rusak ringan $36,57 \mathrm{~km}$ dan rusak berat 4,98 $\mathrm{km}$. Untuk jalan provinsi dalam kondisi baik 456,67 km, sedang 432,96 km, rusak ringan 98,69 km, rusak berat $159,59 \mathrm{~km}$ dan belum tembus $61,49 \mathrm{~km}$. Sedangkan jumlah jembatan yang berada di jalan nasional dan provinsi sebanyak 1.550 buah dengan panjang 21.393 meter yang terdiri dari 916 buah sepanjang 13.950 meter di jalan nasional dan 634 buah sepanjang 7.443 meter di jalan provinsi. (Data dari Balai Besar Pelaksanaan Jalan Nasional VI).

\section{Proses Pengadaan Tanah Untuk Pelakasanaan Pembangunan Pelebaran Jalan Raya}

Menurut Kepala SNVT Pelaksanaan Jalan Nasional wilayah VI Provinsi Sulawesi Selatan (wawancara tanggal 7 Februari 2013, jam 10.30 WITA) bahwa pengadaan tanah untuk Pembangunan Jalan Raya Nasional pada Kabupaten Maros, Kabupaten Pangkep dan Kabupaten Barru dimulai sejak tahun 2008 yang merupakan gagasan dari mantan wakil presiden Indonesia bapak Jusuf Kalla, yang kemudian melaukan MOU (memorandum of understanding) kepada Pemerintah Provinsi Sulawesi Selatan dan setiap kabupaten yaitu Kabupaten Maros, Kabupaten Pangkep dan Kabupaten Barru dimana Mou tersebut memuat bahwa dalam hal proses pengadaan tanah untuk pelaksanaan pembangunan pelebaran jalan raya dilaksanakan oleh masing-masing Kabupaten dengan berkoordinasi dengan pihak-pihak yang terkait.

Dalam MOU pembangunan jalan raya tersebut juga mengatur mengenai hal-hal yang menyangkut pembebasan lahan dan pekerjaan fisik jalan raya tersebut, jadi dalam hal ini pembebasan lahan menjadi tugas Pemerintah Daerah lalu pengerjaan fisik mejadi tugas dari Kementrian Pekerjaan Umum Direktorat Jendral Bina Marga, Balai Besar Pelaksanaan Jalan Nasional VI Makassar, yang dimana anggaran dari peroyek tersebut terdiri dari APBN dan juga APBD.

Untuk lahan yang diperlukan dalam pembangunan fisik jalan nasional tersebut Kepala Satuan Kerja Kementerian Pekerjaan Umum Direktorat Jendral Bina Marga (Balai Besar Pelaksanaan Jalan Nasional VI Makassar), akan 


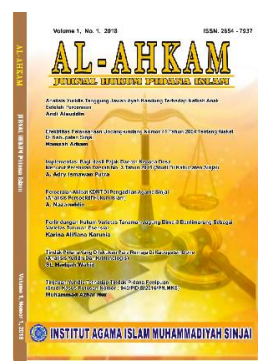

melakukan pengerjaan jalan tersebut apabila masing-masing kabupaten telah mengirimkan data lahan bebas pada ruas jalan nasional yang berada di tiga kabupaten yaitu Kabupaten Maros, Kabupaten pangkajene dan kepulauan (Pangkep) dan Kabupaten Barru.

1. Kabupaten Maros

Menurut Staf Pemerintahan Kabupaten Maros (Wawancara tanggal 14 Februari 2009) bahwa Panitia Pengadaan Tanah, Sekretariat Panitia Pengadaan Tanah dan Satuan Tugas (SATGAS) yang terdiri dari berbagai unsur masingmasing berkoordinasi agar kegiatan pengadaan tanah dimaksud berlangsung efektif, lancar dan terdapat sinkronisasi didalam pelaksanaan pengadaan tanah. Kemudian beliau mengatakan bahwa pemberian ganti rugi sudah melalui rekening bank dimana hal ini berbeda dengan tahun-tahun 2009 dan 2010 yang pembayaran ganti kerugian diberikan secara langsung kepada warga, baik itu di Kantor Kecamatan maupun langsung ke rumah warga.

Dalam hal ini penulis sangat mengapresiasi langkah-langkah Pemerintah Kabupaten Maros yang sangat menghargai dan memahami warganya kemudian tidak adanya unsur pemaksaan dalam proses pembebasan lahan untuk pembangunan jalan raya poros Maros-Pangkep tersebut, hanya saja kekurangannya adalah proyek yang di targetkan rampung pada akhir tahun 2010 terus molor sampai sekarang, tetapi yang perlu kita sukuri bahwa pemerintah Kabupaten Maros tidak berpangku tangan melihat situasi ini dengan turus melakukan upaya dan mencarikan solusi-solusi yang terbaik dengan bekerja sama dengan pihak-pihak yang terkait agar warga ingin atau bersedia melepaskan lahannya dan sekarang yang tercata belum mau bersedia melepaskan tanahnya yaitu masih 33 orang yang tersebar di Kecamatan Lau sebanyak 29 orang, Kecamatan Bontoa 1 orang kemudian dikecamatan Turikale ada 3 orang. Namun apabila belum terjadi kesepakatan maka jalan terakhir adalah dengan melakukan gugatan ke Pengadilan seperti yang di kemukakan diatas dan ini menurut penulis langkah terkahir yang harus dilakukan Pemerintah Kabupaten Maros apabila ingin menyelesaikan proyek pelebaran jalan raya poros Maors-Pangkep ini yang harus rampung tahun 2013.

2. Kabupaten Pangkajene dan Kepulauan (Pangkep)

Selama tiga tahun mulai dari tahun 2009 sampai tahun 2012 bahkan sekarang sudah hampir empat tahun berturut - turut, Pemkab Pangkajene Dan Kepulauan melakukan pengukuran tanah dan ganti rugi lahan bagi 1300 warga pemilik lahan sepanjang jalan poros Maros-Barru dari Kalibone, Kecamatan Minasate'ne sampai Butung, Kecamatan Mandalle. Dari Perencanaan awal Tahun 2008, kebutuhan lahan untuk pelebaran jalan poros tersebut adalah 326.264,06 M2 sementara lahan bebas yang ada hanya seluas $177.614,68$ M2, jadi lahan yang harus dibebaskan adalah seluas 34.795 M2 berupa jalan dan jembatan. 


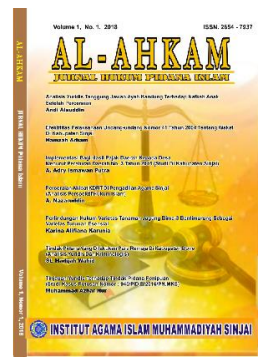

Sekitar kurang lebih sekitar 130 pemilik kembali bersedia memelepaskan hak kepemilikan tanahnya untuk digunakan pada pembangunan pelebaran jalan nasional poros Pangkep-Barru.

Pada pembayaran ganti rugi di Kabupaten Pangkep dilaksanakan dengan dua cara : Pertama, dengan membayarkan/memberikan langsung kepada pemilik hak atas tanah; kedua, dengan melalui rekening bank atas nama warga pemilik hak atas tanah.

Dimana pembanguan pelebaran jalan Nasional ini telah ditergetkan rampung tahun 2013 olehnya itu menurut Staff Pemerintahan Umum Kabupaten Pangkep (wawancara pada tanggal 6 Maret 2013 jam 10.00 WITA) bahwa Pemerintah Provinsi telah memberikan batas waktu yaitu tahun 2013 untuk merampungkan semua pembebasan lahan kepada pemerintah Kabupaten Pangkep yang berada di wilayahnya, olehnya itu Panitia pengadaan tanah yang dibantu Satgas dan instansi terkait melakukan musyawarah rutin dengan warga baik secara individu maupun secara kolektif agar warga dapat bersedia melepaskan/menyerahkan haknya atas tanah untuk pembangunan jalan nasional Poros Pangkep-Barru, lanjut beliau mengatakan bahwa kendala yang dihadapi pemerintah disini karena warga tidak setuju dengan nilai ganti rugi dan warga ingin melepaskan tanah dan bangunannya apabila pemerintah bersedia membeli semua tanah dan banguan milik warga padahal lahan yang diperlukan pemerintah hanya $4 \times 4 \mathrm{M}^{2}$ dan Pemerintah Kabupaten Pangkep juga harus menyesuaikan besarnya anggaran yang sudah ditetapkan oleh Pemerintah. Ini merupakan masalah yang serius karena apabila tidak ada solusi maka pembangunan pelebaran jalan akan sulit terealisasi

Sampai saat ini pemerintah Kabupaten Pangkep masih berupaya mencarikan solusi yang tepat agar pembebasan tanah dapat terealisasi sesuai waktu yang telah ditantukan, dan langkah terkahir yang akan dilakukan oleh pemerintah Kabupaten Pangkep apabila warga yang tanahnya terkena pembagunan pelebaran jalan tidak bersedia melepaskan hak atas tanahnya adalah dengan konsinyasi dan melalui gugatan ke Pengadilan.

3. Kabupaten Barru

Pada Pelaksanaan Pengadaan Tanah di Kabupaten Barru dimulai dari Surat Keputusan Bupati Nomor 461 tertanggal 27 November 2007 Tentang Penetapan Lokasi Pembangunan Pelebaran Poros Jalan Negara Kabupaten Barru yang menetapkan Bahwa Lokasi Pembangunan Pelebaran Jalan Negara dilaksanakan sepanjang poros Jalan Negara di Kabupaten Barru, yang panjang jalan nasionalnya adalah $72 \mathrm{Km}$ yang tersebar di 5 Kecamatan yaitu Kecamatan Tanete Rilau, Kecamatan Barru, Kecamatan Balusu, Kecamatan Soppeng Riaja dan Kecamatan Mallusetasi. 


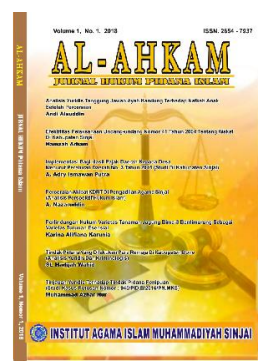

Menurut Kepala Bagian Pertanahan Pemerintahan Kabupaten Barru (Wawancara pada 6 Maret 2013 Jam 14.00) bahwa masi ada dua orang yang belum dibayarkan ganti rugi atas tanah, tanaman dan bangunan namun pemilik lahan tersebut telah mencapai kata sepakat dengan pemerintah, lanjut beliau bahwa salah satu keberhasilan pengadaan tanah di Kabupaten Barru telah selesai dilakukan yaitu keterlibatan pihak-pihak seperti pemuka agama atau tokoh-tokoh masyarakat yang secara langsung melakukan pendekatan secara persuasif kepada warga agar secara sadar untuk melepaskan lahannya untuk pembangunan pelebaran jalan raya nasional poros Barru-Parepare ini.

4. Gambaran Umum Pengadaan Tanah untuk Pembangunan Jalan Raya Nasional Di Sulawesi Selatan

Dalam Pembangunan Pelebaran Jalan di Sulawesi Selatan dalam Proyek Pembangunan Jalan Raya Nasional Maros-Barru aturan yang digunakan adalah Peraturan Presiden Nomor Nomor 36 tahun 2005 jo. Peraturan Presiden 65 Tahun 2006 Tentang Pengadaan Tanah Bagi Pelaksanaan Pembangunan Untuk Kepentingan Umum, dan Undang-Undang-Undang Nomor 2 Tahun 2012 tentang Pengadaan Tanah Bagi Pembangunan Untuk Kepentingan Umum. Pada Pasal 2 Pepres Nomor 65 Tahun 2006 mengutarakan bahwa Pengadaan tanah bagi pelaksanaan pembangunan untuk kepentingan umum oleh pemerintah atau pemerintah daerah dilaksanakan dengan cara pelepasan atau penyerahan hak tas tanah. Selanjutnya, dijelaskan bahwa pengadaan tanah selain bagi pelaksanaan pembangunan untuk kepentingan umum oleh pemerintah atau pemrintah daerah dapat dilakukan dengan cara jual beli, tukar menukar, atau cara lain yang disepakati secara sukarela oleh pihak-pihak yang bersangkutan.

Pada proyek pembangunan jalan raya nasional di Sulawesi selatan juga sangat menjungjung tinggi penghormatan terhadap hak-hak atas tanah karena pemerintah provinsi yang memberikan wewenang kepada masing-masing pemerintah dareah (Maros, Pangkep dan Barru) untuk melaksanakan penyedian lahan/ tanah untuk pembangunan jalan raya Nasional tersebut, dalam hal ini tidak satu pun masyarakat yang penulis wawancarai memperoleh intimidasi, ditakuttakuti sampai di ancam untuk menyerahkan tanahnya. Namun menurut penulis inilah titik lemah dari aturan pengadaan tanah mengapa karena tidak adanya suatu power (kekuatan) yang diberikan oleh aturan untuk melaksanakan/mengeluarkan kebijakan untuk masyarakat yang tidak mau menyerahkan tanahnya, hal ini senada dengan Kepala Bagian Pertanahan Kabupaten Barru (wawancara pada tanggal 6 Maret 2013 jam 13.30 WITA) bahwa aturan lama yaitu Pepres Nomor 65 tahun 2006 membuat pemerintah daerah tidak dapat berbuat banyak mengenai pelaksanaan pengadaan tanah karena tidak bersifat eksekutorial walaupun dalam pasal 18 di perbolehkan untuk melaukan pencabutan hak namun pemerintah juga enggan untuk melaksanakan, dan lanjut beliau setelah Undang-undang Nomor 2 


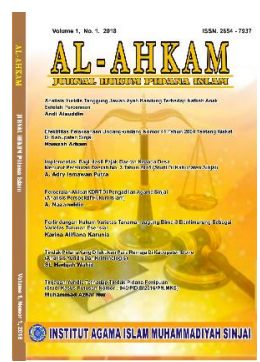

tahun 2012 di sahkan maka dapat melakukan gugatan di pengadilan kemudian pengeksekusiannya juga melalui perantara pengadilan yang dibantu oleh aparat kepolisian, olehnya itu menurut beliau aturan-tersebut sangat membantu pemerintah dalam hal pengadaan tanah.

Proyek pembangunan jalan raya nasional yang di Sulawesi Selatan dalam hal pelaksanaan pengadaan tanah yang dilakukan oleh Pemerintah Daerah Secara garis besar atau gambaran umumnya melalui tahap-tahap sebagai berikut :

1. Pembentukan Panitia Pengadaan Tanah.

2. Pembentukan Tim Penilai

3. Pembentukan SATGAS

4. Mekanisme Pengadaan Tanah

Secara keseluruhan setelah melakukan pengamatan secara langsung di lapangan dan melakukan telaah dokumen juga mewawancarai pejabat pemerintahan yang mengetahui atau berwenang dalam pengadaan tanah untuk pembangunan jalan raya nasional poros Maros-Barru ini bahwa menurut penulis belum optimal karena aturan yang telah ada belum mampu mengakomodasi kepentingan pemerintah dan masyarakat sehingga pelaksanaan pengadaan tanah bagi pembangunan untuk kepentingan umum tidak dapat terealisasi dengan baik.

\section{B. Faktor-faktor yang mempengaruhi pelaksanaan pelebaran jalan raya}

Pelaksanaan pembangunan untuk pembangunan yang memerlukan tanah dalam teori tidak selalu berbanding sama dengan praktek yang terjadi di lapangan. Seperti yang terjadi di pelaksanaan pembangunan jalan raya nasional maros-barru, yang di pengaruhi oleh faktor-faktor sebagai berikut : Substansi hukum, struktur hukum, peran serta masyarakat dan ganti rugi.

\section{Faktor Subtansi Hukum}

Untuk mengetahui sejauh mana pengaruh subtansi hukum yang menjadi faktor belum optimalnya pengadaan tanah bagi pembangunan untuk kepentingan umum dapat dilihat bahwa 15 responden menunjukkan bahwa proses pengadaan tanah untuk kepentingan umum pada pembangunan jalan raya nasional marosbarru sebanyak 14 orang atau 93\% yang menjawab telah sesuai dengan aturan yang berlaku dan hanya 1 orang atau $7 \%$ yang menjawab tidak sesuai dengan aturan yang berlaku, namun sampai saat ini proyek pembangunan jalan raya nasional ini belum selesai sehingga dapat kita mengambil kesimpulan bahwa subtansi hukum dalam aturan pengadaan tanah belum mengakomodasi kepentingan-kepentingan pemerintah dan masyarakat.

\section{Struktur Hukum}

Mengenai kinerja dari apatratur pelaksana dalam pengadaan tanah pada pembangunan jalan nasional Maros-Barru, dapat diketahui 15 responden terdapat 10 orang atau $67 \%$ yang menjawab bahwa posisi pemerintah dan masyarakat 


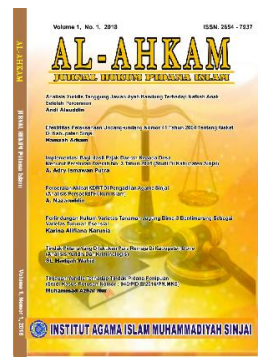

dalam pengadaan tanah seimbang dan terdapat 5 orang atau $33 \%$ yang menjawab posisi antara pemerintah dan masyarakat tidak seimbang, hal ini menunjukkan bahwa masih ada masyarakat yang merasa bahwa aparatur pelaksana dalam pengadaan tanah untuk kepentingan umum masi berpihak kepada penguasa sehingga tidak memperhatikan kepentingan masyarakat yang menyebabkan masyarakat menjadi korban atau pihak yang tidak diuntungkan.

\section{Peran Serta Masyarakat}

Sehubungan dengan masalah peran serta masyarakat dalam pembangunan jalan raya nasional Maros-Barru ini dapat diketahui bahwa dari 15 responden terdapat 9 orang atau $60 \%$ jawaban yang menjawab bahwa masyarakat berperan dalam pembangunan pelebaran jalan raya nasional Maros-Barru dan terdapat 6 orang atau $40 \%$ yang menjawab tidak berperan, dari jawaban diatas menunjukkan bahwa peran serta masyarakat dalam pembangunan pelebaran jalan raya nasional maros-barru masih kurang. Hal ini perlu adanya penyuluhan hukum mengenai aturan-atauran pertanahan agar menumbuhkan kesadaran masyarakat untuk terlibat dan berperan serta dalam hal pembangunan untuk kepentingan umum yang berimbas pada kesejahteraan masyarakat itu sendiri.

4. Ganti Rugi

Sehubungan dengan masalah ganti rugi dapat dilihat bahwa $73 \%$ masyarakat yang telah menerima ganti rugi yang menjawab ganti rugi yang diberikan sudah adil atau telah memenuhi rasa keadilan masyarakat dan $27 \%$ yang menjawab tidak adil. Namun menurut wawancara penulis kepada beberapa warga yang menyatakan bahwa ganti kerugian sebenarnya jauh dari harga pasar namun warga pasrah menerima ganti kerugian yang ditawarkan oleh pemerintah. Hal ini menunjukkan adanya kesewenang-wenangan dalam hal penetapan ganti kerugian.

Pada pembangunan jalan raya nasional Maros-Barru ini masih ada beberapa warga yang enggan melepaskan tanahnya untuk pembangunan jalan raya, dari pengamatan penulis dan hasil wawancara dari masyarakat dan pemerintah bahwa yang menjadi penyebab sehingga ganti kerugian tidak dapat di berikan kepada warga atau warga tidak setuju dengan besarnya ganti kerugian, ada beberapa faktor yang mempengaruhi sebagai berikut :

a) Adanya diskriminasi pemerintah terhadap warga

b) Nilai ganti kerugian yang belum mencapai kata sepakat

c) Adanya Orang-Orang Atau Organisasi Yang Menunggangi Atau Mempengaruhi Masyarakat

d) Besarnya Objek Ganti Rugi

\section{Daftar Pustaka}

Ahman Husein Hasibuan, 1986, Masalah Perkotaan Berkaitan Dengan Urbanisasi dan Penyediaan Tanah, Makalah 


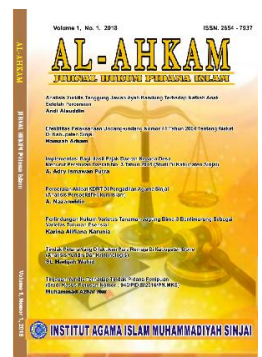

Achmad Rubaie, 2007, Hukum Pengadaan Tanah Untuk Kepentingan Umum, BayuMedia, Malang.

Aminuddin Salle, 2007, Hukum Pengadaan Tanah Untuk Kepentingan Umum,

Cet. Pertama, Kreasi Total Media, Jogjakarta.

Arie Sukanti Hutagalung dan Markus Gunawan, 2009, Kewenagan Pemerintah di Bidang Pertanahan, Rajawali Pers, Jakarta.

B.F. Sihombing, 2004, Evolusi Kebijakan Pertanahan dalam Hukum Tanah Indonesia, PT.Toko Gunung Agung, Jakarta.

Effendi Perangin, 1991, Hukum Agraria Indonesia, Suatu Telaah Dari Sudut Pandang Praktisi Hukum, Rajawali, Jakarta.

Eka Irene Sihombing, 2009, Segi-Segi Hukum Tanah Nasional Dalam

Pengadaan Tanah Untuk Pembangunan, Cet. Kedua, Universitas Trisakti, Jakarta.

George Whitecross Paton, 1951 ,“A Text-Book of Jurisprudence”, Oxford at The Clarendon Press, London. Ronny Hanitjo Soemitro, 1990,Metodologi Penelitian Hukum dan Jurimetri, Ghalia Indonesia, Jakarta.

Gunanegara, 2008, Rakyatdan Negara, Cetakan Pertana, tatanusa, Jakarta.

Herman Hermit, 2004, Cara Memperoleh Sertipikat Tanah Hak Milik, Tanah Negara dan Tanah Pemda, Teori dan Praktek Pendaftaran Tanah di Indonesia, Mandar Maju, Bandung.

Iman Soetiknjo, 1983, Politik Agraria Nasional, Cetakan Ke-1, Gamma University Press, Yogjakarta.

I Wayan Suandra, 1994, Hukum Pertanahan Indonesia, Rineka Cipta, Jakarta.

Irwan Soerodjo, 2003, Kepastian Hukum Hak Atas Tanah Di Indonesia, Arkola, Jakarta.

Imam Koeswahyono, 2008, Melacak Dasar Konstitusional Pengadaan Tanah untuk Kepentingan Pembangunan Bagi Umum, dimuat dalam Artikel Jurnal Konstitusi Vol.1, Mahkamah Konstitusi RI, Jakarta.

John Salindeho, 1988, Masalah Tanah dalam Pembangunan, Cetakan Kedua, Sinar Grafika, Jakarta.

Maria S. W. Sumardjono, 2001, Kebijakan Pertanahan Antara Regulasi dan Implementasi, Cetakan I, Kompas, Jakarta.

M Hadjon dan Tatiek Sri Djatmiati, 2005, Argumentasi Hukum, Cetakan Kedua,: Gadjah Mada University Press, Yogyakarta.

Peter Mahmud Marzuki, 2005, Penelitian Hukum, Kencana, Jakarta.

Olan Sitorus dan H. M Zaki Seirrad, 2006, Hukum Agraria Konsep Dasar dan Implementasi, Mitra Kebijakan Tanah Indonesia, Yogjakarta.

Sufirman Rahman, 2006, Hukum Pengadaan Tanah Untuk Kepentingan Umum dari Prespektif Hak Azasi Manusia, UNHAS, Makassar. 
Volume 3, No. 1, 2021

ISSN (print) : 2654-7937

ISSN (online) : 2715-0313

Homepage : http://journal.iaimsinjai.ac.id/index.php/al-ahkam/index

Tatit Januar Habibi, 2007, Pelaksanaan Penetapan Ganti Rugi dan Bentuk Pengawasan Panitia Pengadaan Tanah Pada Proyek Pembangunan Teriminal Bumiayu(Tesis), Universitas Diponegoro Semarang.

Tim Redaksi Tatanusa, 2012, Pengadaan Tanah Bagi Pembagunan Untuk Kepentingan Umum, Tatanusa, Jakarta.

Usep Setiawan, Jurnal Analisis Sosial Vol. 9, No. 1 April 2004 